\title{
Video and seismometer observations of avalanche characteristics in a warm snowy district
}

\author{
Kazuya AKIYAMA', Masaaki HANAOKA ${ }^{2}$ and Toshiya TAKESHI ${ }^{3}$ \\ 1 Niigata Experimental Laboratory, Public Works Research Institute, Arai, 944-0051 Japan \\ [Now in Sabo Technical Center, Chiyoda-ku, Tokyo, 102-0074 Japan] \\ 2 Niigata Experimental Laboratory, Public Works Research Institute, Arai, 944-0051 Japan \\ [Now in Shinjo Office of River, Shinjo, 996-0071 Japan] \\ 3 Public Works Research Institute, Tsukuba, 305-8516 Japan
}

(Received August 10, 2011; Revised manuscript accepted January 19, 2012)

\begin{abstract}
Observation stations were established on the east side of Mt. Gongendake, central Japan, in a warm snowy region where air temperature often exceeds $0^{\circ} \mathrm{C}$ in winter. Meteorological data were measured and avalanche events were recorded using a seismometer and three video cameras. Over four winters, 1504 avalanche tremors and 727 avalanche video images were recorded. The video images included 83 dry surface avalanches, four dry full-depth avalanches, 157 wet surface avalanches, and 483 wet full-depth avalanches. Among these avalanches, 431 were on slope S1, where a disastrous avalanche occurred on January 26, 1986. Wet avalanches represented about $88 \%$ of the avalanches and took place when the air temperature was high. Approximately $92 \%$ of dry surface avalanches occurred while snow was falling. When dry surface avalanches occurred, calculated snow stability index $(S I)$ values were below 4 and conditions for avalanche release from within the snow cover were satisfied. Wet avalanches occurred frequently during and after March, when the air temperature continuously exceeded $0^{\circ} \mathrm{C}$, and even occurred in January and February when the air temperature was high. Wet full-depth avalanches increased in frequency as snowmelt increased. Starting in midMarch, most avalanches were wet full-depth avalanches, whereas in April only wet full-depth avalanches occurred.
\end{abstract}

Key words: video observation, avalanche tremor observation, dry avalanche, wet avalanche, snow stability index

\section{Introduction}

Although the best way to study avalanche development is by direct observation of the release points of natural avalanches, post-disaster surveys greatly outnumber studies based on widespread and continu ous monitoring. Previous avalanche monitoring studies in Japan have included periodic photography of avalanche events (Narita and Shimizu, 1975, 1976, 1977, 1978) and video recordings of avalanches at Toikanbetsu (Horonobe Town, Hokkaido Prefecture; Akitaya, 1973). Loads created by the impact force of avalanches were measured in Shiai-dani Valley in Kurobe Canyon, Toyama Prefecture (Shimizu et al., 1972, 1973, 1974, 1975, 1978). In a latter study, avalanche observations in Shiai-dani have included a range of techniques, such as video recording, avalanche impact-force measurement, tremor measurements (ground vibrations caused by avalanches) using seis- mometers. This research also carried the artificial avalanche experiments and yield extensive information about avalanche dynamics. (Kurobe Avalanche Measurement Group, 1989). At Kanisawashinden (Shiozawa Town, Niigata Prefecture), avalanches were recorded using a video camera and three seismometers, and the detection level of avalanche tremors was assessed by comparing microtremors with artificial vibrations (Muramatsu, 1993).

A more recent study detected avalanches using a video camera, a seismometer, and other instruments in the winter of 2000-2001 at Makunosawa Valley (Myoko, Niigata Prefecture), where five large-scale avalanches were recorded over the span of nine winters (Takeuchi et al., 2009). At Toikanbetsu (Horonobe Town, Hokkaido Prefecture), avalanche release point and avalanche scale were estimated using data obtained by two video cameras and four seismometers in 2001 (Imanishi et al., 2004). On the south slope of Happoone (Hakuba Village, Nagano Prefecture), mete- 
orological, video, and seismic data were collected over nine winters (1996 to 2005), and 224 avalanches (predominantly dry surface avalanches) were recorded (Akiyama et al., 2007).

Although observational data are available, timeseries information, such as the timings of avalanches or changes in avalanche type over a single winter, is extremely scarce. The present study collected weather data, video images of avalanches, and avalanche tremor data from December 2000 to March 2005 in Nou Town (now Itoigawa City) in the Maseguchi district, Niigata Prefecture, central Japan. This area has many avalanches, and location conditions permits the collection of detailed measurements of avalanches from their release areas to their deposit areas. This paper reports on the weather condition and avalanche events based on the results of observations performed for 5 winters, beginning in December 2000 and concluding in March 2005.

\section{Study area and methods}

\subsection{Avalanche study area}

The study area was Mt. Gongendake (1104 m a.s.l.) in the western Maseguchi district, about $13 \mathrm{~km}$ upstream from where the mouth of the Nou River flows into the Sea of Japan (Fig. 1). On January 26, 1986, a large avalanche was triggered at about 900 to $1000 \mathrm{~m}$ a.s.l. on the east side slope of Mt. Gongendake at around 11:00 pm, causing a disaster that led to 13 deaths and the partial or total destruction of 11 homes. This avalanche was a mixed flowing and powder type (mainly powder type) dry slab surface avalanche that was $2100 \mathrm{~m}$ long, 200-300 m wide, and had an estimated volume of 1 to $2.5 \times 10^{5} \mathrm{~m}^{3}$ (Kobayashi, 1986). Figure 2 shows the detailed map of Maseguchi district and the scope of the avalanche disaster. Approximately 2.5 hours before this avalanche, another large avalanche occurred at the Shimamichi mineral spring (Shimamichi Kousen) about $3.5 \mathrm{~km}$ west-northwest of the Maseguchi district (Fig. 1). The movement of this avalanche was recorded by a seismometer (Izumi and Kobayashi, 1986), and its speed and impact force on the ground surface were estimated based on the waveform of the avalanche's tremors (Tsukuda and Mizoue, 1988). After the avalanche disaster on January 26, 1986, Niigata Prefecture installed avalanche-guiding dikes, energy dissipation frames, energy dissipation fences, and other avalanche protection facilities (Fig. 2).

The east side slope of Mt. Gongendake (Fig. 3) has a gentle slope between elevations of 250 and $600 \mathrm{~m}$ a.s.l. (landslide ground) and a steep slope from $600 \mathrm{~m}$ a.s.l. to the mountain peak at $1104 \mathrm{~m}$ a.s.l. The east slope above $600 \mathrm{~m}$ a.s.l. was divided according to slope angle into $5^{\circ}$ class intervals using a 50-m digital elevation model (DEM; Fig. 4). Much of the slope is between

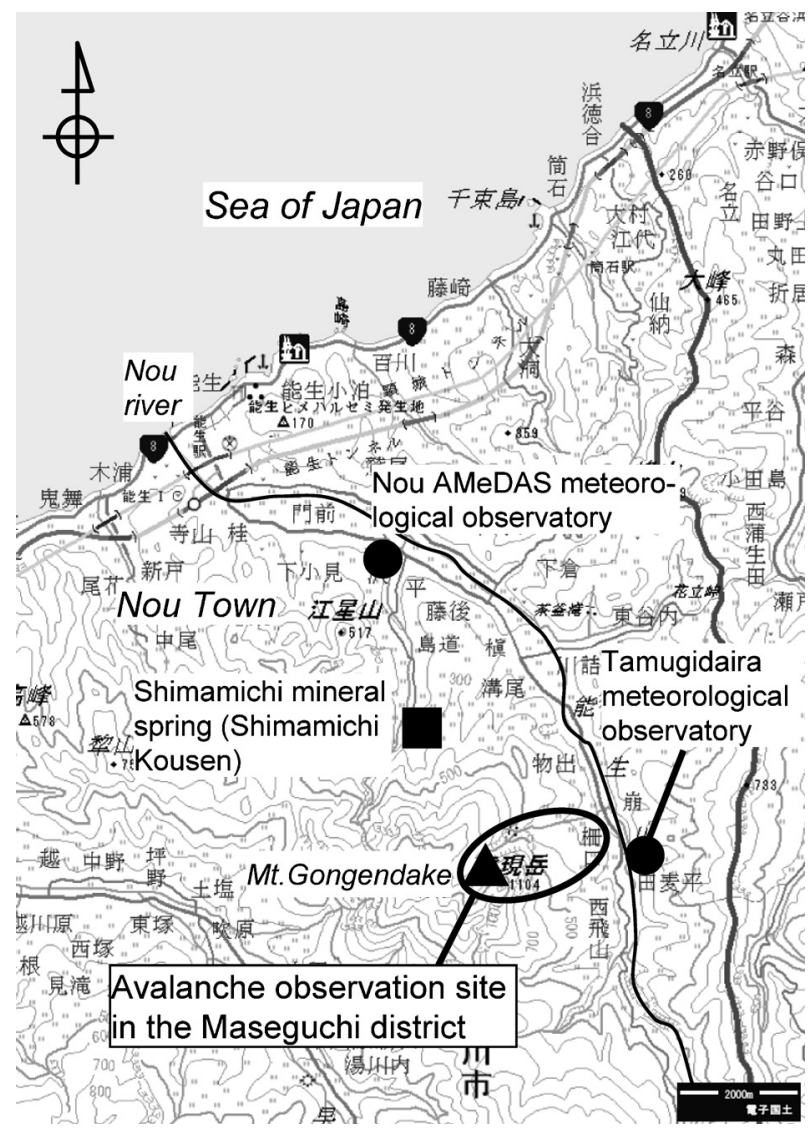

Fig. 1. Location map of the avalanche observation sites. (Background map data based on Digital Japan Web System.)

$35^{\circ}$ and $50^{\circ}$, angles at which avalanches are easily triggered. The avalanche observations focused mainly on the steepest part of the east side slope of Mt. Gongendake, an area from 350 to $1100 \mathrm{~m}$ a.s.l., with a maximum width of $1000 \mathrm{~m}$, and a maximum slope length of $700 \mathrm{~m}$. The east side slope of Mt. Gongendake is divided topographically by ridgelines and flow direction of avalanches. Avalanches released from the north part of the slope flowed northeastward along the small valley, whereas avalanches released from the south part of the slope flowed toward the Hisonomata Valley or the southern base of Mt. Gongendake (Figs. 2 and 3). The central part of the slope studied has eight avalanche chutes along which avalanches flowed eastward (Fig. 3). The large avalanche of January 26, 1986, started in five of these chutes. In this study, the east side slope of Mt. Gongendake can be categorized into five unit slopes: $\mathrm{S} 1$, S2, S3, S4, and H (Figs. 2 and 3).

\subsection{Avalanche observation methods}

Video observation of avalanches is impossible when the slope cannot be seen, such as during heavy snowfall or on moonless nights. Avalanche tremor observations, however, can be performed continuously. In previous studies, avalanche events were detected using seismometers installed along roads 


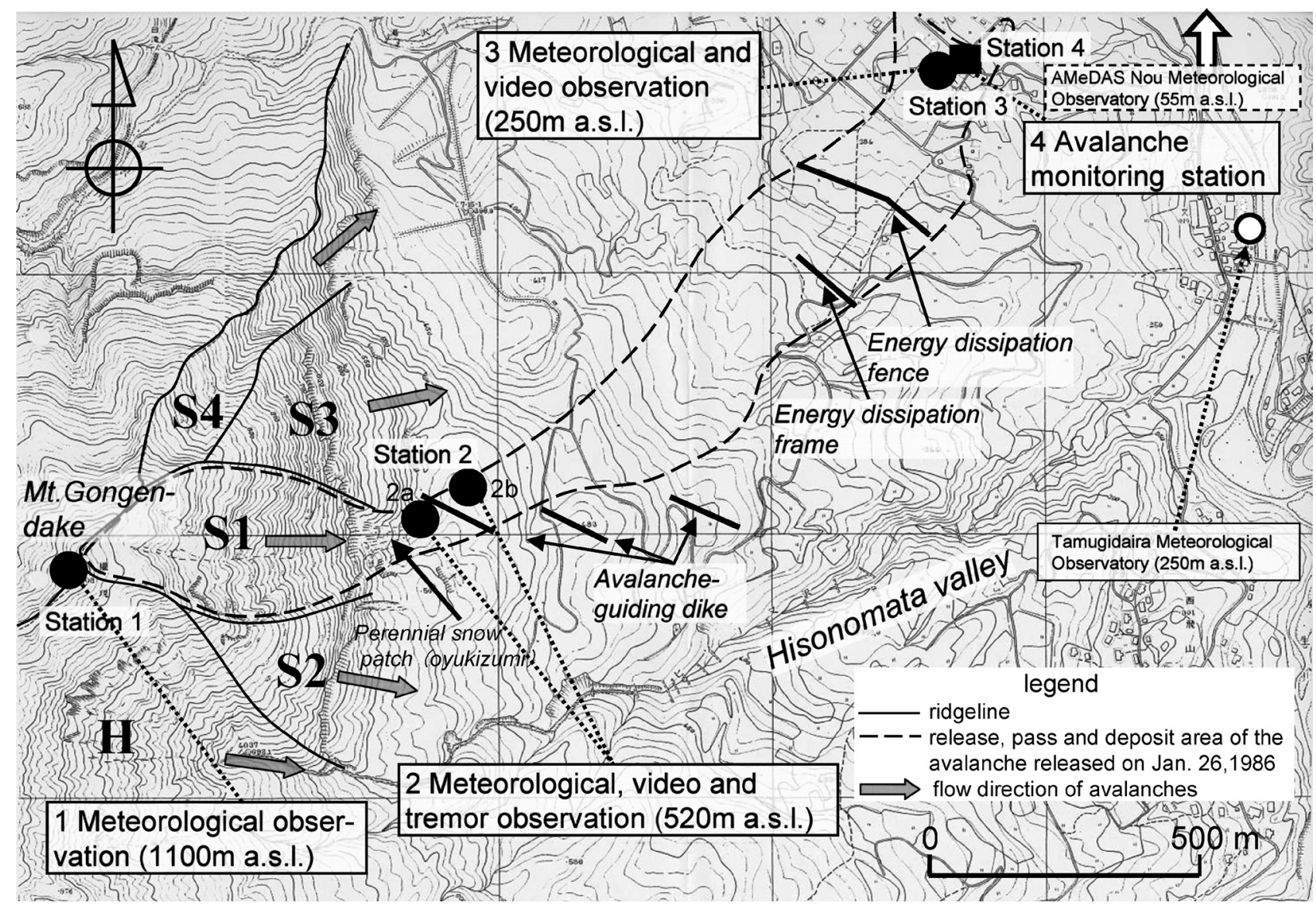

Fig. 2. Detailed map of the avalanche observation sites.

Station 1-3: Meteorological observation and avalanche detection stations.

S1-S4 and H: Topographic subdivisions of the slope.

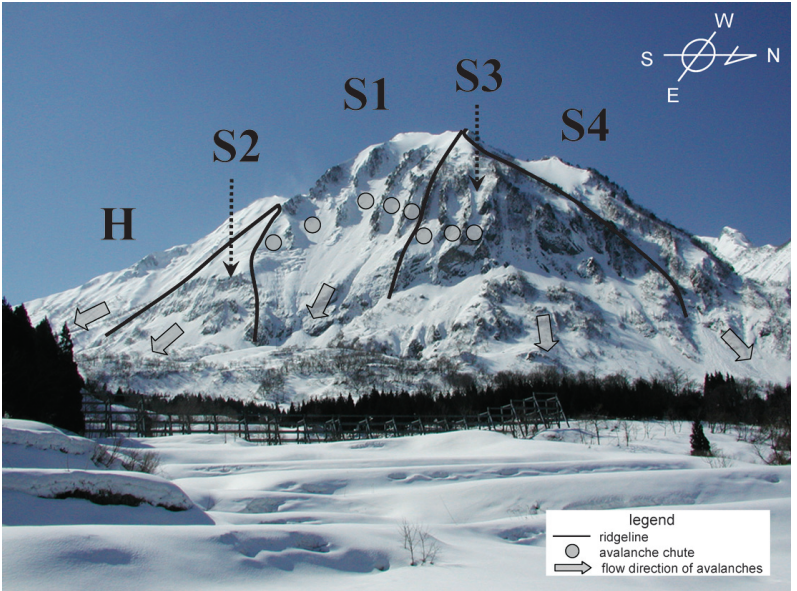

Fig. 3. East side slope of Mt. Gongendake.

S1-S4 and H: Topographic subdivisions of the slope.

(Bessason et al., 2007), and their motion was analyzed by linking avalanche video images to recorded avalanche tremors (Sabot et al., 1998).

Table 1 lists the items observed, and Figure 2 shows the observation stations and types of data collected. Meteorological data were recorded at station 1 , located above the avalanche release area at $1100 \mathrm{~m}$ a.s.l. Station 2 was located on the avalanche pass or deposit area at $520 \mathrm{~m}$ a.s.l. Avalanche tremor obser-

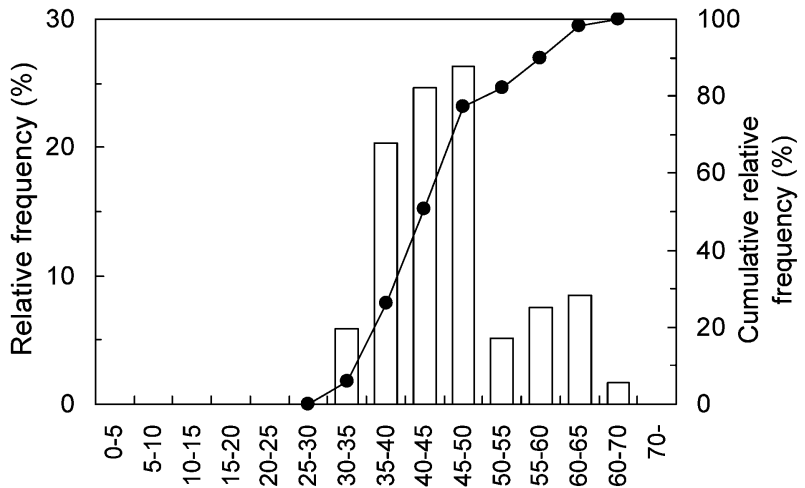

Slope angles (in 5 degrees scale)

Fig. 4. Slope angles of east side slope of Mt. Gongendake above $600 \mathrm{~m}$ a.s.l.

vations were performed at station $2 \mathrm{a}$, on the front of the avalanche-guiding dike (mountain side), and meteorological data and video images of avalanches were recorded at station $2 \mathrm{~b}$, on the back of the avalancheguiding dike. Meteorological and video data were also recorded at station 3 (250 $\mathrm{m}$ a.s.1.). Data from observation stations 1,2 , and 3 were transmitted to the avalanche monitoring station (station 4) using a wireless device, optical fiber cable, and a wired device, and the data were stored with their observation times synchronized using a GPS time-checking system. 
Table 1. Data recorded at 3 stations and details of meteorology and avalanche detection.

\begin{tabular}{|c|c|c|c|c|c|}
\hline \multirow{2}{*}{ No. } & \multirow{2}{*}{ location } & \multirow{2}{*}{ altitude (m) } & \multicolumn{2}{|c|}{ elements and items } & \multirow{2}{*}{ notes } \\
\hline & & & meteorology & avalanche detection & \\
\hline 1 & $\begin{array}{c}\text { at the top of } \\
\text { Mt.Gongendake }\end{array}$ & 1100 & $\begin{array}{l}\text { wind direction, wind speed, air temperature, } \\
\text { snow depth }\end{array}$ & - & $\begin{array}{l}\text { above the avalanche } \\
\text { releace area }\end{array}$ \\
\hline 2 & $\begin{array}{c}\text { at the foot of } \\
\text { Mt.Gongendake }\end{array}$ & 520 & $\begin{array}{l}\text { wind direction, wind speed, air temperature, } \\
\text { air humidity, snow depth, net radiation, } \\
\text { solar radiation, reflected radiation, } \\
\text { temperature on snow surface }\end{array}$ & $\begin{array}{l}\text { visual observation using a video camera, } \\
\text { avalanche tremor observation using a } \\
\text { seismometer }\end{array}$ & $\begin{array}{l}\text { avalanche pass or } \\
\text { deposit area }\end{array}$ \\
\hline 3 & $\begin{array}{c}\text { in the Maseguchi } \\
\text { district }\end{array}$ & 250 & $\begin{array}{l}\text { wind direction, wind speed, air temperature, } \\
\text { precipitation, count of snowfall particle }\end{array}$ & visual observation using two video cameras & $\begin{array}{l}\text { avalanche deposit } \\
\text { area of disaster on } \\
\text { Jan.26,1986 }\end{array}$ \\
\hline
\end{tabular}

Table 1 lists the types of meteorological data that were collected. Snow depth data were also taken from two meteorological stations: the Automated Meteorological Data Acquisition System (AMeDAS, Japan Meteorological Agency) at Nou, located at $55 \mathrm{~m}$ a.s.l. and about $10 \mathrm{~km}$ northwest of Mt. Gongendake, and the Tamugidaira station (Niigata Prefecture), 1ocated at $250 \mathrm{~m}$ a.s.1. and about $2 \mathrm{~km}$ east of Mt. Gongendake (Figs. 1 and 2).

Video image of avalanches was obtained by installing three high-sensitivity cameras. One camera was installed at station $2 \mathrm{~b}$, where slope $\mathrm{S} 1$ could be recorded at close range, and the other cameras were installed at station 3 to record long-range observations of slopes S1 to S4 and part of slope H (Figs. 2 and 3). Video images were recorded at a rate of one frame per second using two time-lapse video recorders capable of long-term recording. At the same time, when ever the measured avalanche tremors exceeded a standard value (discussed below), a pre- and post-alarm recording system triggered video recording on a hard disk at a frequency of 10 frames per second for the time before, during, and after the tremor.

Avalanche tremors were recorded by burying a high-sensitivity electromagnetic velocity meter (SM $111 \mathrm{~S} \cdot 112 \mathrm{~S}$; natural period 1 second, bandwidth 1 to 50 $\mathrm{Hz}$; Tokyo Sokushin Co., Ltd.) at station $2 \mathrm{a}$ to measure ground vibrations in three components (vertical, north-south, and east-west) at a frequency of one measurement per 0.01 seconds. The background microtremors of the ground where the velocity meter was buried were 0.1 mkine $\left(0.1 \times 10^{-3} \mathrm{~cm} \mathrm{sec}^{-1}\right)$ or lower. Measurements were made by establishing a standard value of 0.2 mkine; when the composite value of the three components of ground vibration exceeded the standard value, vibrations were recorded before and after that time.

The observations also included ground vibrations that were not caused by avalanches. Earthquakerelated seismicity was identified by comparing the study data with seismic data from the Nou Earthquake Observational Station (NUJ2; Earthquake Observation Center of the Earthquake Research Institute, University of Tokyo, near Shimamichi Kousen;

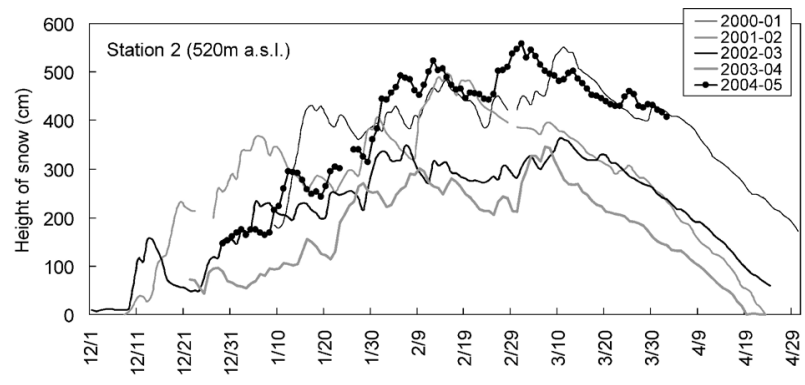

Fig. 5. Snow depth conditions at station 2 for five winters (2000 to 2005).

Fig. 1). The true number of avalanche events was determined by isolating the seismic events that were above the standard value and comparing them to the video data from before and after the time of ground vibration, and then removing those events that were not accompanied by visual evidence of avalanche activity. The complete video dataset was then replayed to confirm the visibility period of the east side slope of Mt. Gongendake and to identify any small avalanche events that were below the standard value for tremor measurements.

Avalanches were classified according to the position of the slip (surface or full-depth) and the water content of the snow (dry or wet). Although dry snow could be assumed for any surface avalanche that was accompanied by an obvious snow cloud, conditions were difficult to classify as dry or wet for those avalanches that lacked a snow cloud. In such cases, snow conditions were classified based on snowfall and changes in air temperature recorded by the meteorological data for the time immediately prior to the avalanche event.

Meteorological observations began in December 2000 at stations 1 and 2, and all observational items were measured for 459 days (four winters, from December 2001 to March 2005).

\section{Results of meteorological observations}

No meteorological data were recorded at station 1 during and after February 2002; thus, the state of snow accumulation for all five winters (2000 to 2005) 

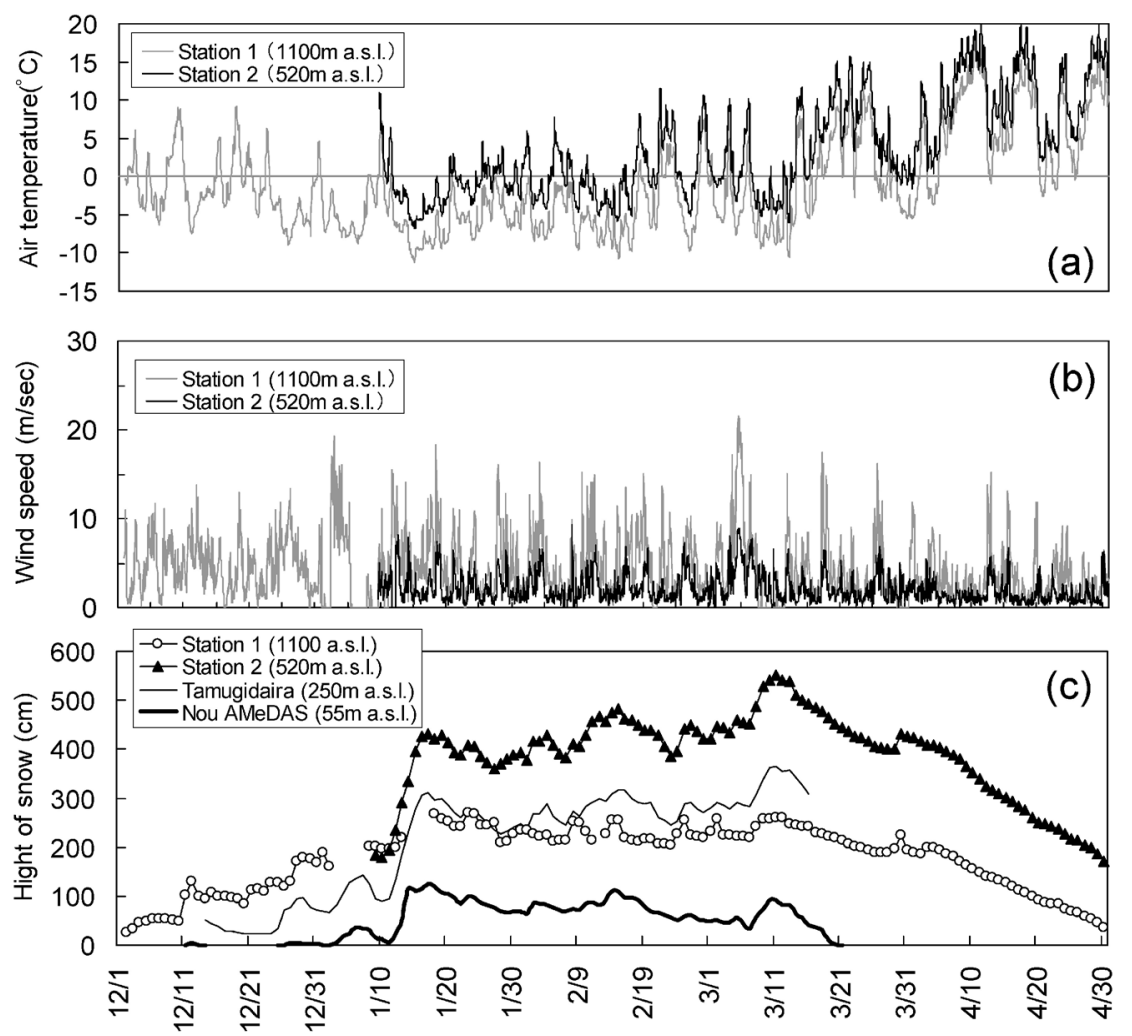

Fig. 6. Meteorological conditions in and near the avalanche study area (Dec. 2000-Apr. 2001).

(a) Air temperature at stations 1 and 2 .

(b) Wind speed at stations 1 and 2 .

(c) Snow depth at stations 1 and 2, and at the Tamugidaira and Nou AMeDAS meteorological observatories.

was based on snow depth data at station 2 (Fig. 5). Maximum accumulated snow depths were $552 \mathrm{~cm}$ in $2000-2001,497 \mathrm{~cm}$ in $2001-2002,360 \mathrm{~cm}$ in $2002-2003,346$ $\mathrm{cm}$ in 2003-2004, and $558 \mathrm{~cm}$ in 2004-2005. Snowfall was heavy in three of the winters (2000-2001, 20012002, and 2004-2005), when maximum snow depth was about $5 \mathrm{~m}$.

Air temperature, wind speed, and snow depth data for stations 1 and 2 for the winter of 2000-2001 were augmented with snow depth data from the Nou AMeDAS and Tamugidaira meteorological observatories (Fig. 6). The study area is warm but snowy, and air temperature often exceeds $0^{\circ} \mathrm{C}$ in winter. Although there were times when the air temperature at station 1 was higher than at lower elevations (thermal inversion), the total duration of thermal inversions was only about $1 \%$ of the observation interval, and overall the temperature decreased at approximately $0.72^{\circ} \mathrm{C}$ per $100 \mathrm{~m}$ of elevation. Wind speed was highest at station 1 with wind directions predominantly from west- southwest to northwest (70\% of the observation interval). Snow depth increased with elevation (at Nou AMeDAS, Tamugidaira, and station 2), with the exception of locations near the peak of Mt. Gongendake (station 1), where accumulated snow was assumed to have been blown eastward by the predominantly westerly wind. Occasionally, rain fell instead of snow. The air temperature at the snowfall-
Table 2. Number of observation days, detected tremors, and avalanche video images.

\begin{tabular}{c|c|c|c}
\hline winter & $\begin{array}{c}\text { number of } \\
\text { observation } \\
\text { days }\end{array}$ & $\begin{array}{c}\text { number of } \\
\text { tremors }\end{array}$ & $\begin{array}{c}\text { number of } \\
\text { avalanche } \\
\text { images }\end{array}$ \\
\hline $2001 \sim 2002$ & 118 & 437 & 215 \\
\hline $2002 \sim 2003$ & 125 & 397 & 228 \\
\hline $2003 \sim 2004$ & 122 & 273 & 129 \\
\hline $2004 \sim 2005$ & 94 & 397 & 155 \\
\hline 4 winters & 459 & 1504 & 727 \\
\hline
\end{tabular}

rainfall boundary was about $2^{\circ} \mathrm{C}$ according to the data from stations 2 and 3.

\section{Characteristics of avalanche detections}

\subsection{Results of avalanche tremor and avalanche video observations}

Avalanche tremor and video observations were performed for 459 days spanning four winters (December 2001 to March 2005; Table 2). During this time, 3386 tremors were recorded. Four types of vibrations were recorded: 1504 ground vibrations caused by avalanches (about $44 \%$ of the total), 1518 seismic vibra- 


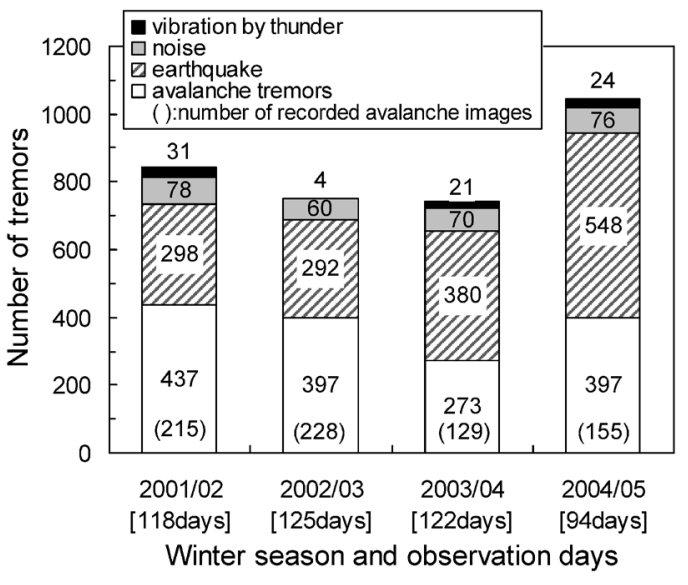

Fig. 7. Types of detected tremors.

tions (about 45\%), 80 ground vibration events caused by thunder, and 284 short vibration events with durations of about 1 to 5 seconds (Fig. 7). Ground vibrations caused by avalanches and seismicity were common every winter, and approximately 270 to 440 tremors caused by avalanches were recorded each winter. Among the four winters, the winter of 2003-2004 had the lowest snow accumulation and also the fewest avalanche tremors. Numerous earthquakes occurred in the winter of 2004-2005, but many of these were aftershocks following the Niigata Prefecture Chuetsu Earthquake of 23 October 2004. Lightning strikes were verified using video images and associated thunder was isolated in the tremor dataset. It was not possible to link tremors of 1 to 5 second duration to a particular cause, but ground vibrations caused by avalanches were obvious because they had durations of at least 5 seconds.

Of the 1504 ground vibrations caused by avalanches, 727 (about 48\%) were confirmed to be avalanches based on simultaneous video recordings. Avalanches that occurred during heavy snowfall or darkness could not be confirmed visually. The slopes of Mt. Gongendake were not visible during about $40 \%$ of the video record from station $2 \mathrm{~b}$ and about $50 \%$ of the video record from station 3 by an investigation in 1-hour units of the visible or invisible range of the object spanning four winters.

Video images permitted identification of 727 avalanches and their classification according to slope zone (Fig. 8). During the four winters studied, 707 (about $97 \%$ ) of the avalanches started on slopes S1, S2, and S3, of which 431 were on slope S1 (about 59\%). Classification according to avalanche type (Fig. 9) shows that most were wet avalanches: the 640 wet avalanches (about $88 \%$ of the total) included 157 wet surface avalanches and 483 wet full-depth avalanches. Dry avalanches represented about $12 \%$ of the events (87 events), including 83 dry surface avalanches and four dry full-depth avalanches, which occurred only in the winters of 2001-2002 and 2002-2003.

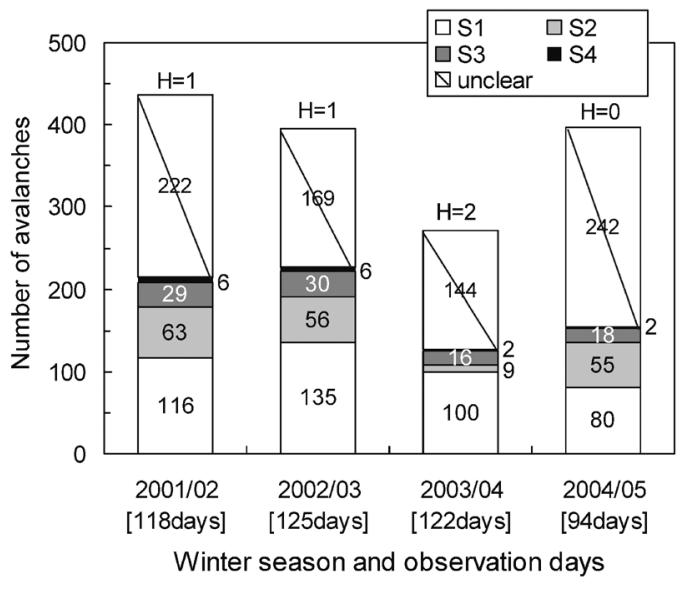

Fig. 8. Number of avalanches classified according to slope identity, based on avalanche video images. Unclear data are events recorded only in the seismic data.

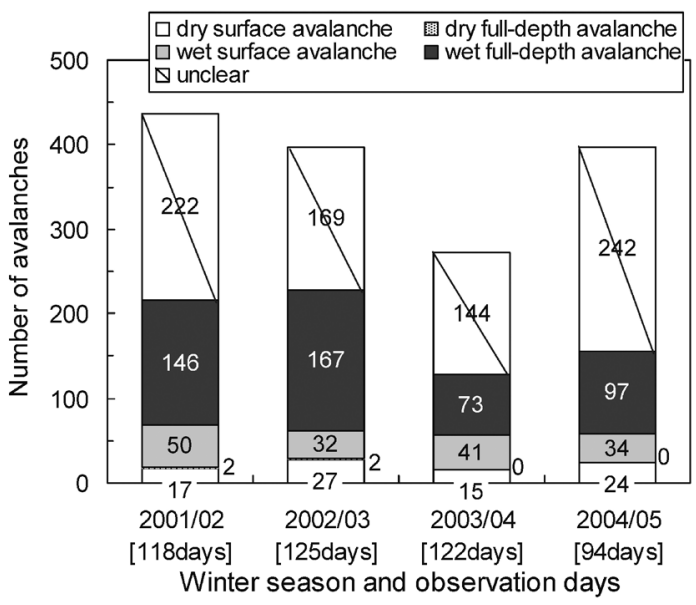

Fig. 9. Classification of avalanche type based on avalanche video images. Unclear data are events recorded only in the seismic data.

In a few instances, video records indicated the occurrence of an avalanche at a time when simultaneous ground vibrations were not recorded, but these were extremely small avalanches such as sluff (dry point-starting surface avalanches) for which ground vibrations did not exceed the threshold value. None of the video images recorded snow avalanches caused by the collapse of snow cornices, even though snow cornices were present every year along the ridgeline of Mt. Gongendake.

\subsection{Characteristics of avalanche tremors}

Previous research found that avalanche tremors are characterized by the following: (a) a spindle shape that, unlike an earthquake waveform, increases in amplitude as the avalanche flows downhill and then decreases, (b) a dominant frequency of $30 \mathrm{~Hz}$ or less with peaks near $10 \mathrm{~Hz}$, and (c) a peak of the running power spectrum of the waveform that is shifted in response to the avalanche flow (Nishimura and Izumi, 
1997). The distance from the avalanche release point to seismometers $(L)$ correlates negatively with the dominant frequency of the avalanche tremor waveform $(f)$. Moreover, the total squares of the vibration amplitude of the waveform $(I)$ and the distance from the avalanche release point to the seismometer $(L)$ can be used to estimate the mass of the avalanche $(M)$, indicating the scale of an avalanche event (Imanishi et al., 2004).

Waveforms obtained through observations of avalanche tremors (vertical component) are shown in Figure 10. This figure shows an example from the winter of 2002-2003, when dry full-depth avalanches occurred. The first to tenth avalanche tremor waveforms in Figure 10 were caused by avalanches on slopes S1 to S3 and had spindle shapes that developed because the vibration amplitude increased and then decreased as the avalanches flowed downward. The eleventh and twelfth avalanche tremor waveforms in Figure 10, with waveforms of small amplitude and
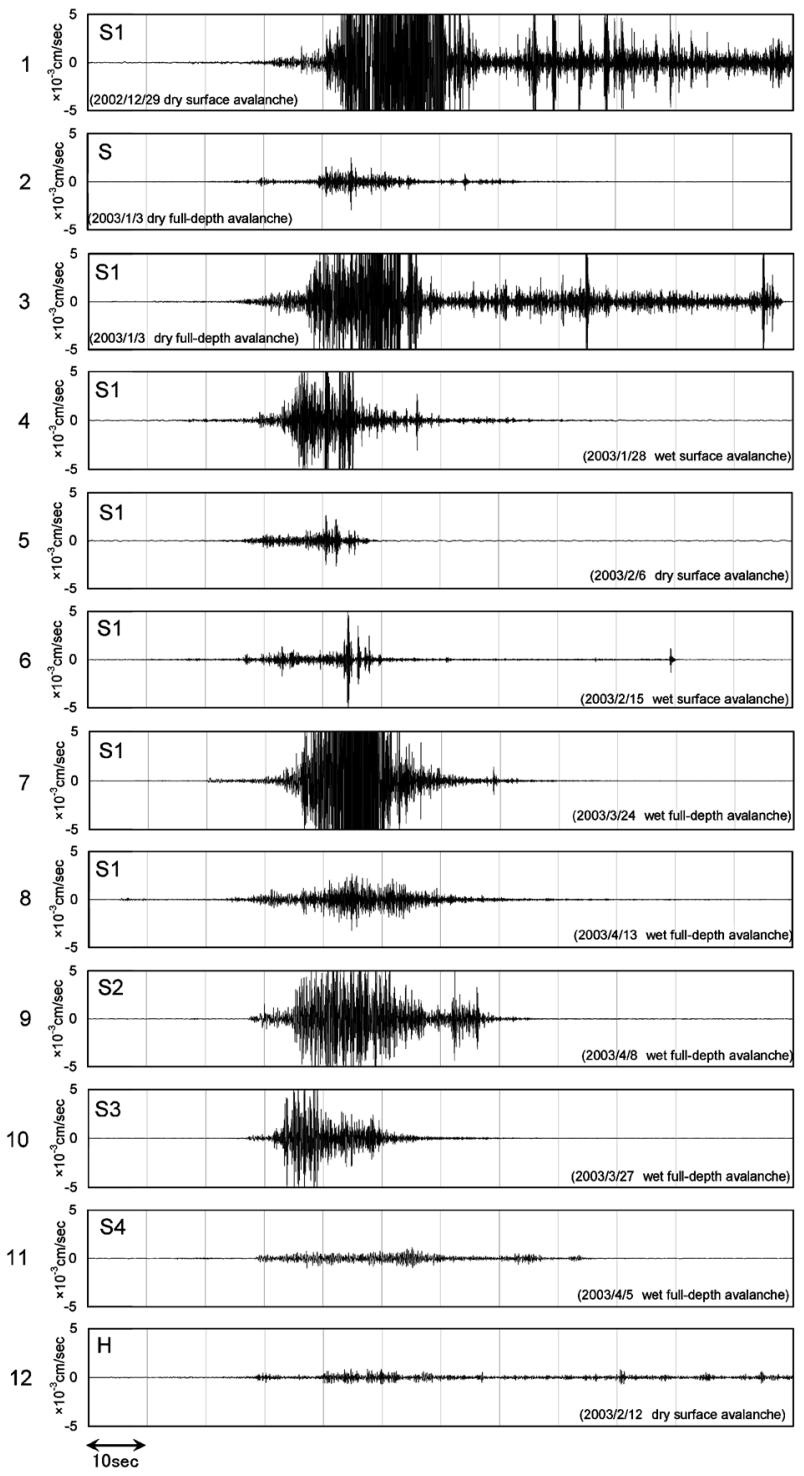

Fig. 10. Examples of avalanche tremors (vertical motion) in winter 2002-2003. long duration, were caused by avalanches on slopes S4 and $\mathrm{H}$, respectively.

Figure 11 shows the relationship between the dominant frequency of avalanche tremor waveforms during the ground vibration caused by avalanches $(f)$ and duration of the waveform according to the unit slopes where the avalanches occurred. The dominant frequencies of the avalanche tremors were from 2 to $16 \mathrm{~Hz}$, with many between 7 and $11 \mathrm{~Hz}$. The dominant frequencies of the tremors associated with avalanches on slope S1 were almost all between 6 and $13 \mathrm{~Hz}$. The dominant frequencies of the tremors associated with avalanches released on slopes S2 and S3 were between 3 and $11 \mathrm{~Hz}$, with many between 5 and 9 Hz. The dominant frequencies of avalanche tremors on slopes $\mathrm{S} 4$ and $\mathrm{H}$ were between 2 and $5 \mathrm{~Hz}$. Avalanche movements on slopes S1, S2, and S3 were close to the seismometer installed at station $2 \mathrm{a}$, but avalanches on slopes $\mathrm{S} 4$ and $\mathrm{H}$ were farther from the seismometer. The high-frequency component attenuates as the avalanche-related vibration is transmitted through the snow and ground, such that the dominant frequency of waveforms decreases with distance.

When the scale of an avalanche was calculated based solely on its tremors, it was difficult to determine the distance $(L)$ from the avalanche release point to the seismometer because many avalanches occurred everywhere on slopes S1, S2, and S3. Thus, avalanche scale was calculated by taking the total squares of the vibration amplitude of the waveform $(I)$, without considering the distance $(L)$. Figure 12 shows the relationship of the dominant frequency of waveforms $(f)$ and the total of the squares of the

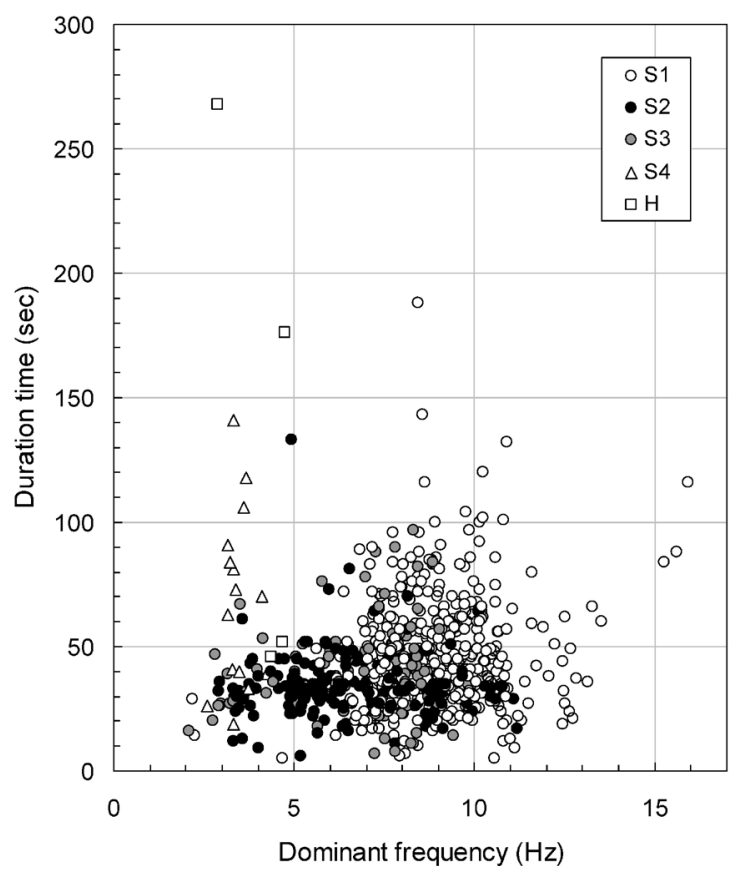

Fig. 11. Relation between dominant frequency and duration of avalanche tremors (vertical motion). 


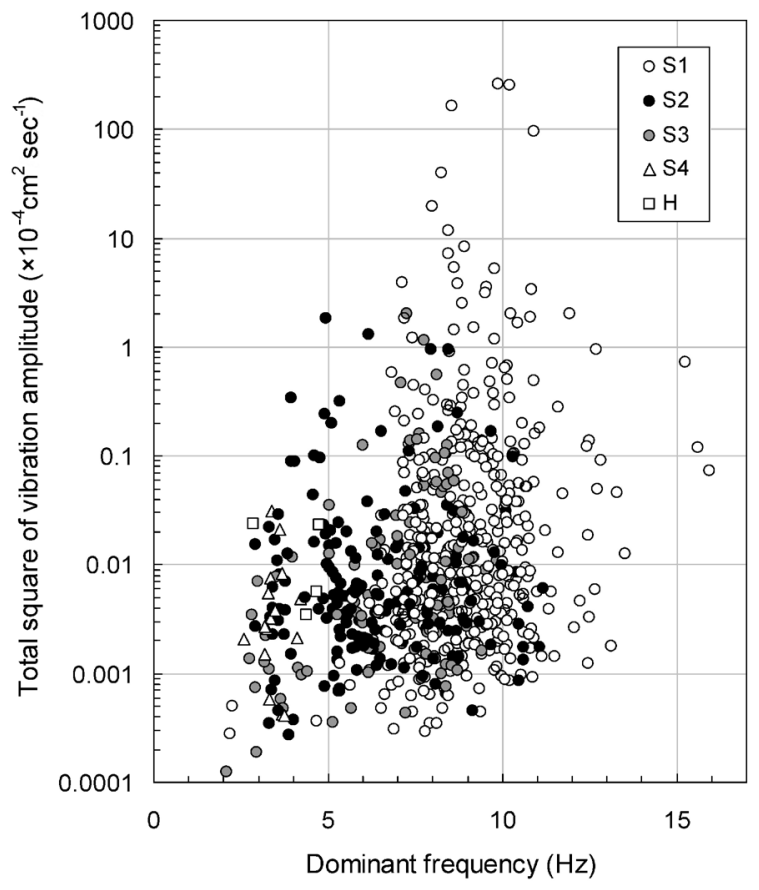

Fig. 12. Relation between dominant frequency and the total squares of the avalanche tremor vibration amplitude (vertical motion).

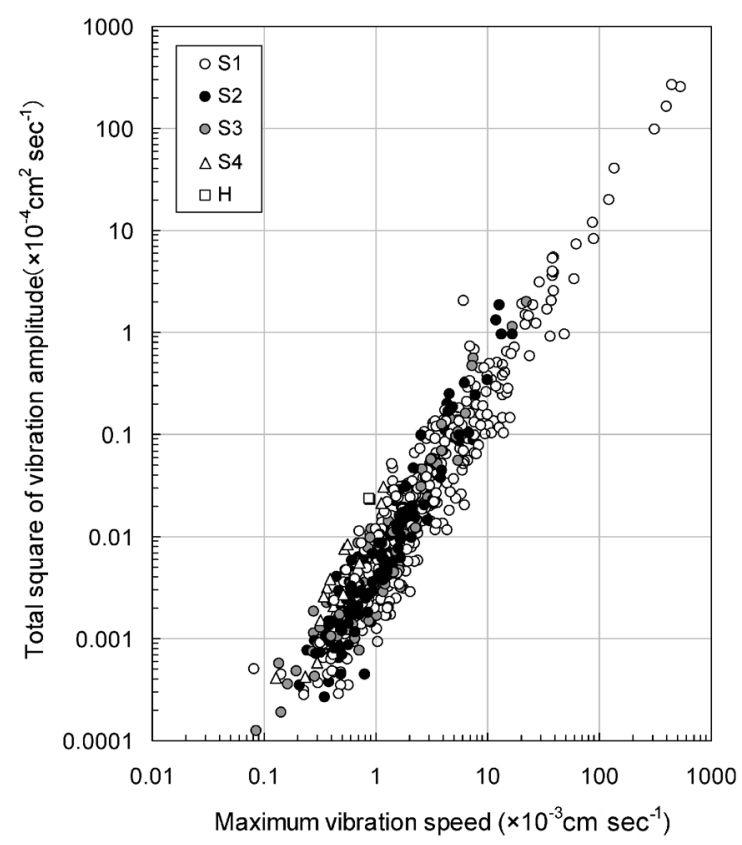

Fig. 13. Relation between maximum vibration speed and the total squares of the avalanche tremor vibration amplitude (vertical motion).

vibration amplitude of the waveform (I) according to the unit slopes. The dominant frequency of large avalanches $\left(I>5 \times 10^{-4} \mathrm{~cm}^{2} \mathrm{sec}^{-1}\right)$ was 8 to $11 \mathrm{~Hz}$ for all avalanches released on slope $\mathrm{S} 1$. In cases where the dominant frequency of small waveforms was $5 \mathrm{~Hz}$ or lower and the avalanche was small $\left(I<0.001 \times 10^{-4}\right.$ $\left.\mathrm{cm}^{2} \mathrm{sec}^{-1}\right)$, either attenuation of tremors took place even though the event was near the seismometer, or the original tremor did not contain a higher frequency component.

An example of the relationship between the maximum vibration speed of the avalanche tremor and the total squares of the vibration amplitude of the waveform $(I)$ is shown in Figure 13. Because the maximum vibration speed is between 0.08 and 530 mkine $\left(10^{-3}\right.$ $\mathrm{cm} \mathrm{sec}^{-1}$ ) and correlates with the square of the vibration amplitude, it is possible to calculate the scale of an avalanche using the maximum vibration speed, without performing any other calculation (such as the total squares of the vibration amplitude).

\section{Weather conditions and avalanche timing}

5.1 Calculating the snow stability index and snowmelt

Of the 83 dry surface avalanches identified using video records, 76 (about 92\%) occurred while snow was falling. Wet avalanches occurred often when the air temperature was high. The snow stability index $(S I)$ of the snow layer and quantity of snowmelt on the snow surface were calculated, and their respective relationships with avalanche occurrence were compared. The elevations at which avalanches occurred ranged from 600 to $1100 \mathrm{~m}$ a.s.1., and thus the snow stability and snowmelt criteria were calculated at the elevation of station 2 (520 $\mathrm{m}$ a.s.1.).

Calculation of the snow stability index $(S I)$ is based on the shear stress $\tau\left(\mathrm{N} \mathrm{m}^{-2}\right)$ and shear strength SFI $\left(\mathrm{N} \mathrm{m}^{-2}\right)$ inside the snow layer (Roch, 1966):

$$
S I=S F I / \tau \text {. }
$$

The shear stress $\tau$ is the component of force in the direction of incline of the snow load $\mathrm{W}\left(\mathrm{N} \mathrm{m}^{-2}\right)$ per unit of horizontal area of snow on a slope, with inclination represented by $\theta$ :

$$
\tau=W \cdot \cos \theta \cdot \sin \theta .
$$

The probability of avalanche occurrence is high when SI values are below 4 (Roch, 1966). The snow stability index $(S I)$ was calculated using the method of Suizu (2002), based on the method of Endo (1993); assumptions for this calculation were that the initial new snow density was $60 \mathrm{~kg} \mathrm{~m}^{-3}$ and the slope gradient was 45 degrees. The air temperature and wind speed values were those recorded at station $2 \mathrm{~b}$, whereas the total precipitation was obtained at station 3 . When the temperature was below $2^{\circ} \mathrm{C}$, the precipitation was considered to be snowfall. Catch ratios of snowfall (solid precipitation) obtained at station 3 decreased with increasing wind speed, and thus solid precipitation was corrected based on wind speed (Ohno et al., 1998) to calculate the snow load. The snow stability index was calculated at intervals of 6 hours to obtain an $S I$ value for the bottom surface of each layer of accumulated snow, with the minimum $S I$ value treated as the snow stability index (SI) of the overall accumulated snow; this calculation was made for 
times before the air temperature continuously exceeded $0^{\circ} \mathrm{C}$. The daily snowmelt volume was calculated using the heat balance method (Kojima, 1979) and meteorological data from station $2 \mathrm{~b}$. The number of avalanches by type per day, and the scales of avalanches released on slopes S1, S2, and S3 were evaluated based on the total squares of the vibration amplitude of the waveform $(I)$.

\subsection{Weather conditions and avalanche events in winter 2001-2002}

Figure 14 shows the meteorological conditions, daily snowmelt, avalanche events, and variation in the snow stability index (SI) for the winter of 20012002. Air temperature at stations 1 and 2 exceeded $0^{\circ} \mathrm{C}$ from January 10 to 12 , January 20 to 21 , February 5 to 8 , February 16 to 17 , February 20 to 22 , and February 25 to March 2, and often exceeded $0^{\circ} \mathrm{C}$ continuously after March 9. Continuous snowfalls were recorded from December 26 to January 5, January 16 to 19, January 27 to February 1, and February 9 to 19, but little snowfall occurred during and after March. Daily snowmelt could be calculated almost continuously after February 3, and the calculated amount of daily snowmelt was often more than $20 \mathrm{~mm}$ after March 15. The highest calculated amount of daily
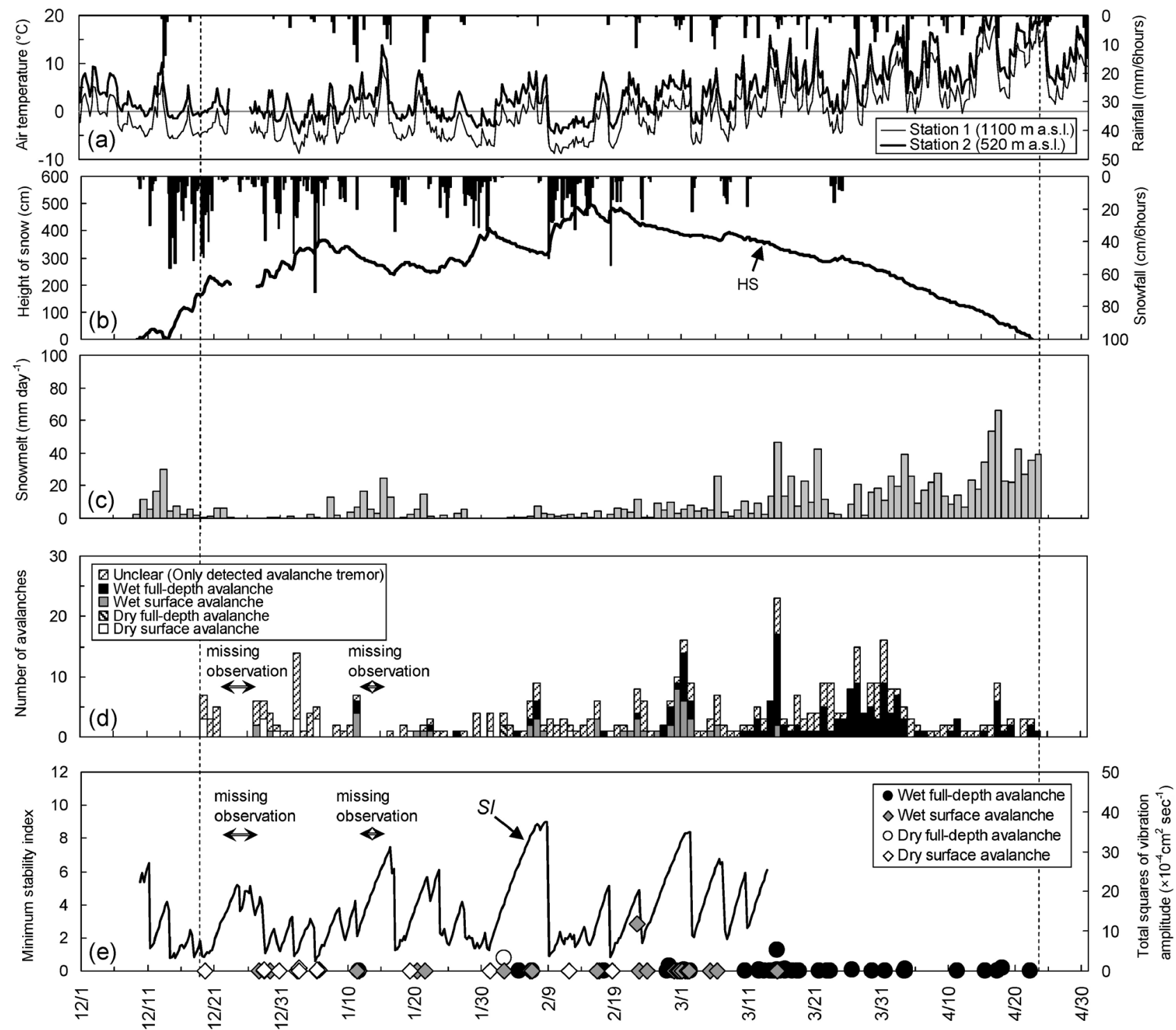

Fig. 14. Meteorological conditions, daily snowmelt, avalanche events, and variation in the snow stability index (Dec. 2001Apr. 2002).

(a) Air temperature at station 1 (calculated using temperature lapse rate: $0.72{ }^{\circ} \mathrm{C} / 100 \mathrm{~m}$ from station 2 ) and at station 2 , and rainfall at station 3 .

(b) Snow depth and snowfall at station 2.

(c) Daily snowmelt (calculated for station 2).

(d) Number of avalanches per day, based on avalanche tremor and video records. 'Unclear' refers to events recorded only in the seismic data.

(e) Snow stability index (calculated) and the total squares of vibration amplitude of avalanche tremors (vertical motion) on slopes S1, S2, and S3. 
snowmelt was about $66 \mathrm{~mm}$ on April 17.

The video record contained 17 dry surface avalanches, two dry full-depth avalanches, 50 wet surface avalanches, and 146 wet full-depth avalanches. Dry surface avalanches were recorded when SI values ranged from 0.9 to 3.0. A dry surface avalanche released on January 19 occurred after snowfall at an SI value of 3.0, and the other dry surface avalanches occurred during snowfall when $S I$ values ranged from 0.9 to 2.1. No dry surface avalanches were present in the video record after February 19. Two dry fulldepth slab avalanches occurred on the hillside of Mt. Gongendake on February 2. The snowfall that began on January 27 and lasted until the avalanche release times increased the snow depth by $97 \mathrm{~cm}$ (cumulative difference per hour of $187 \mathrm{~cm}$, precipitation $97 \mathrm{~mm}$ ) according to values measured at stations $2 \mathrm{~b}$ and 3 . The increased load produced by the continuous snowfall is assumed to have caused these two dry fulldepth avalanches.

Wet surface avalanches occurred four times on January 11, six times from February 6 to 8, three times on February 16, and 29 times from February 20 to March 6. No wet surface avalanches were present in the video record after March 16. Wet full-depth avalanches occurred twice on January 11, four times from February 6 to 7 , and 17 times from February 26 to March 2. Only wet full-depth avalanches occurred after March 16, when the air temperature recorded at stations 1 and 2 almost continuously exceeded $0^{\circ} \mathrm{C}$; wet avalanches typically occurred when the air temperature at station 1 exceeded $0^{\circ} \mathrm{C}$ or daily snowmelt increased.

The wet surface avalanche triggered on slope S1 on February 22 was large (based on the total squares of the vibration amplitude of the waveform $(I>5 \times$ $10^{-4} \mathrm{~cm}^{2} \mathrm{sec}^{-1}$ ), and the duration of its tremor waveform was 88 seconds. This avalanche was the largest in 2001-2002. The large wet full-depth avalanche on slope S1 on March 15 took place when the daily snowmelt amount was calculated to be approximately 47 $\mathrm{mm}$. This was a wet slab full-depth avalanche and the duration of its tremor waveform was 50 seconds.

\subsection{Weather conditions and avalanche events in winter 2002-2003}

Figure 15 shows the meteorological conditions, daily snowmelt, avalanche events, and variation in the snow stability index (SI) for the winter of 20022003. Air temperature at stations 1 and 2 exceeded $0^{\circ} \mathrm{C}$ from December 23 to 25, January 13 to 14 , January 16 to 17 , January 27 to 28 , February 7 to 11 , and March 1 to 3 , and often exceeded $0^{\circ} \mathrm{C}$ continuously after March 23. Continuous snowfalls were recorded from December 25 to 30, January 4 to 8 , January 20 to 23 , January 29 to February 1, February 5 to 6, February 11 to 12 , March 1 to 3 , and March 8 to 11 , but there was little snowfall after March 12. Calculations show that daily snowmelt was produced almost continuously during the observation interval, and snow cover often melted at a rate of more than $20 \mathrm{~mm}$ per day after March 23. The highest calculated amount of daily snowmelt was approximately $67 \mathrm{~mm}$ on April 8 .

The video records contained 27 dry surface avalanches, two dry full-depth avalanches, 32 wet surface avalanches, and 167 wet full-depth avalanches. Dry surface avalanches took place when $S I$ values ranged from 0.8 to 2.6. Two dry surface avalanches released on January 3 occurred after snowfall at an SI value of 2.6 , and the other dry surface avalanches occurred during snowfall when $S I$ values ranged from 0.8 to 2.4 . The video record contains no dry surface avalanches after February 13. Two dry full-depth avalanches occurred near the summit of Mt. Gongendake on January 3; the waveforms of their avalanche tremors are shown in Figure 10. The snowfall from December 25 to the avalanche release time increased the snow depth by $115 \mathrm{~cm}$ (cumulative difference per hour 180 $\mathrm{cm}$, precipitation $147 \mathrm{~mm}$ ) according to measurements at stations $2 \mathrm{~b}$ and 3 . The increased load produced by the continuous snowfall is assumed to have caused the two dry full-depth avalanches.

Wet surface avalanches occurred twice on January 13 , four times from January 17 to 20, four times from January 27 to 28, 10 times from February 8 to 11, and five times from February 25 to March 2; no wet surface avalanches were recorded after March 20. Wet full-depth avalanches occurred five times from January 17 to 20,16 times from February 7 to 11 , seven times from February 26 to March 3, and 13 times from March 16 to 18 . Wet full-depth avalanches occurred after March 23 when the air temperature at stations 1 and 2 almost continuously exceeded $0^{\circ} \mathrm{C}$; wet avalanches typically occurred when the air temperature at station 1 exceeded $0^{\circ} \mathrm{C}$ or daily snowmelt increased.

A large dry surface avalanche $\left(I>5 \times 10^{-4} \mathrm{~cm}^{2} \mathrm{sec}^{-1}\right)$ on slope S1 on December 29 took place during snowfall when the $S I$ value was 1.1. This avalanche was accompanied by a snow cloud and the duration of its avalanche tremor waveform was 132 seconds (Fig. 10). The large wet full-depth avalanche triggered on March 24 on slope S1 was a wet slab full-depth avalanche with a tremor waveform duration of 86 seconds (Fig. 10); this was the largest avalanche in the winter of 2002-2003.

\subsection{Weather conditions and avalanche events in winter 2003-2004}

Figure 16 shows the meteorological conditions, daily snowmelt, avalanche events, and variation in the snow stability index (SI) for the winter of 20032004. Air temperature at stations 1 and 2 exceeded $0^{\circ} \mathrm{C}$ from December 28 to 29, December 31 to January 2, February 1 to 3, February 13 to 14, February 19 to 23, 

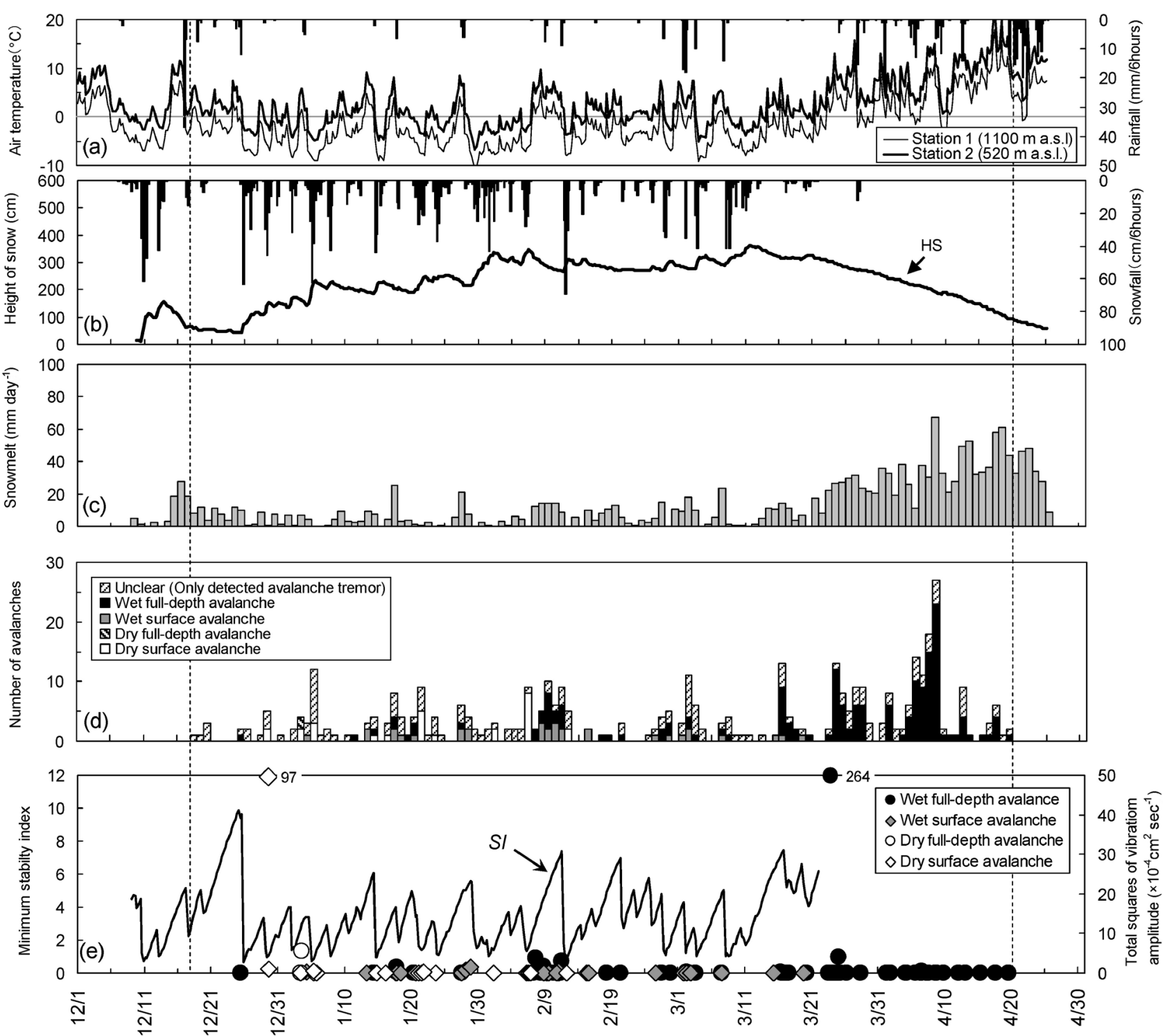

Fig. 15. Meteorological conditions, daily snowmelt, avalanche events, and variation in the snow stability index (Dec. 2002Apr. 2003).

(a) Air temperature at station 1 (calculated using temperature lapse rate: $0.72^{\circ} \mathrm{C} / 100 \mathrm{~m}$ from station 2 ) and at station 2 , and rainfall at station 3 .

(b) Snow depth and snowfall at station 2.

(c) Daily snowmelt (calculated for station 2).

(d) Number of avalanches per day, based on avalanche tremor and video records. 'Unclear' refers to events recorded only in the seismic data.

(e) Snow stability index (calculated) and the total squares of seismic amplitude of avalanche tremors (vertical motion) on slopes S1, S2, and S3.

February 25 to 26, February 28 to 29 , March 9 to 11 , and March 16 to 18 , and often exceeded $0^{\circ} \mathrm{C}$ continuously after March 23. Continuous snowfalls were recorded from December 26 to 27, January 13 to 17, January 22 to 29, February 2 to 9, February 15 to 16 , and March 2 to 7, but little snowfall occurred after March 8. Daily snowmelt was produced almost continuously from February 8 to 26 and after March 5 . The highest calculated amount of daily snowmelt was about $79 \mathrm{~mm}$ on February 22, and snow cover often melted at a rate of more than $20 \mathrm{~mm}$ per day after March 10.

The video data recorded 15 dry surface ava- lanches, no dry full-depth avalanches, 41 wet surface avalanches, and 73 wet full-depth avalanches. Dry surface avalanches were recorded when SI values ranged from 0.9 to 3.2. Two dry surface avalanches released on January 31 occurred after snowfall at $S I$ values of 3.0 and 3.2, and the other dry surface avalanches occurred during snowfall, when SI values ranged from 0.9 to 2.3. No dry surface avalanches were present in the video record after February 24.

Wet surface avalanches occurred three times from December 28 to January 3, seven times from February 1 to 2 , seven times from February 8 to 10,12 times from February 19 to 26, and seven times from March 


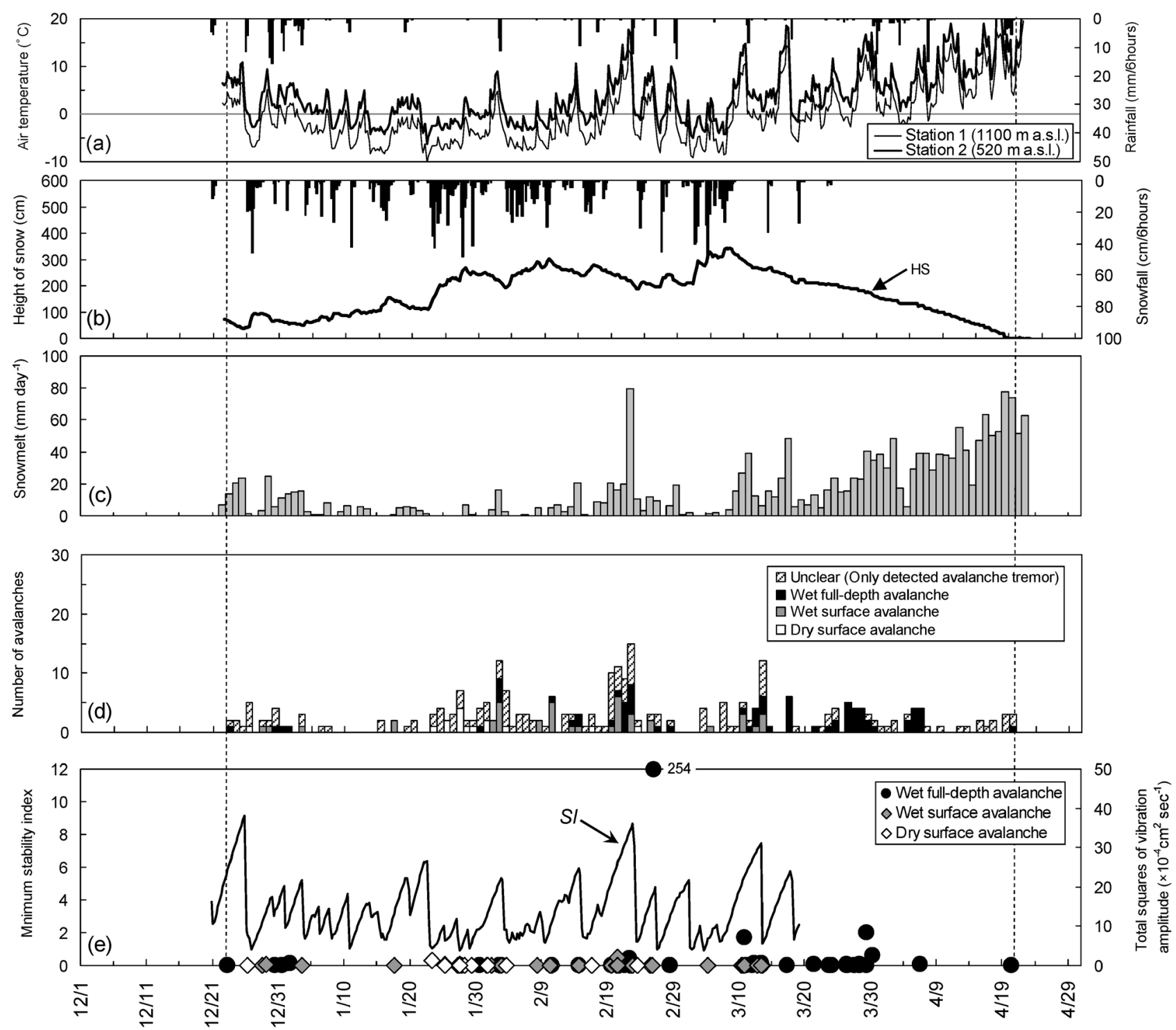

Fig. 16. Meteorological conditions, daily snowmelt, avalanche events, and variation in the snow stability index (Dec. 2003Apr. 2004).

(a) Air temperature at station 1 (calculated using temperature lapse rate: $0.72^{\circ} \mathrm{C} / 100 \mathrm{~m}$ from station 2 ) and at station 2 , and rainfall at station 3 .

(b) Snow depth and snowfall at station 2.

(c) Daily snowmelt (calculated for station 2).

(d) Number of avalanches per day, based on avalanche tremor and video records. 'Unclear' refers to events recorded only in the seismic data.

(e) Snow stability index (calculated) and the total squares of seismic amplitude of avalanche tremors (vertical motion) on slopes S1, S2, and S3.

10 to 13 ; no wet surface avalanches were recorded after March 14. Wet full-depth avalanches occurred three times from December 30 to January 1, four times on February 2, 12 times from February 19 to 22, nine times from March 10 to 14, and six times on March 17. After March 14, only wet full-depth avalanches occurred, when the air temperature at stations 1 and 2 continuously exceeded $0^{\circ} \mathrm{C}$. Wet avalanches were associated with increased air temperature caused by low atmospheric pressure from February 19 to 22, when the maximum air temperature at station 1 exceeded $14^{\circ} \mathrm{C}$. These conditions are similar to those measured in the avalanche observations on the south slope of Happoone (Hakuba Village, Nagano Prefecture; Akiyama et al., 2007).

The wet full-depth avalanche triggered on slope S1 on February 26 was large $\left(I>5 \times 10^{-4} \mathrm{~cm}^{2} \mathrm{sec}^{-1}\right)$ and the maximum vibration speed of its waveform (vertical motion) was 530 mkine $\left(5.3 \times 10^{-3} \mathrm{~cm} \mathrm{sec}^{-1}\right)$. This wet slab full-depth avalanche had a tremor waveform duration of 120 seconds and was the largest avalanche of 2003-2004. Two wet slab full-depth avalanches triggered on slope S1 on March 10 and March 29 were also large and had tremor waveforms lasting 188 and 83 seconds, respectively. 

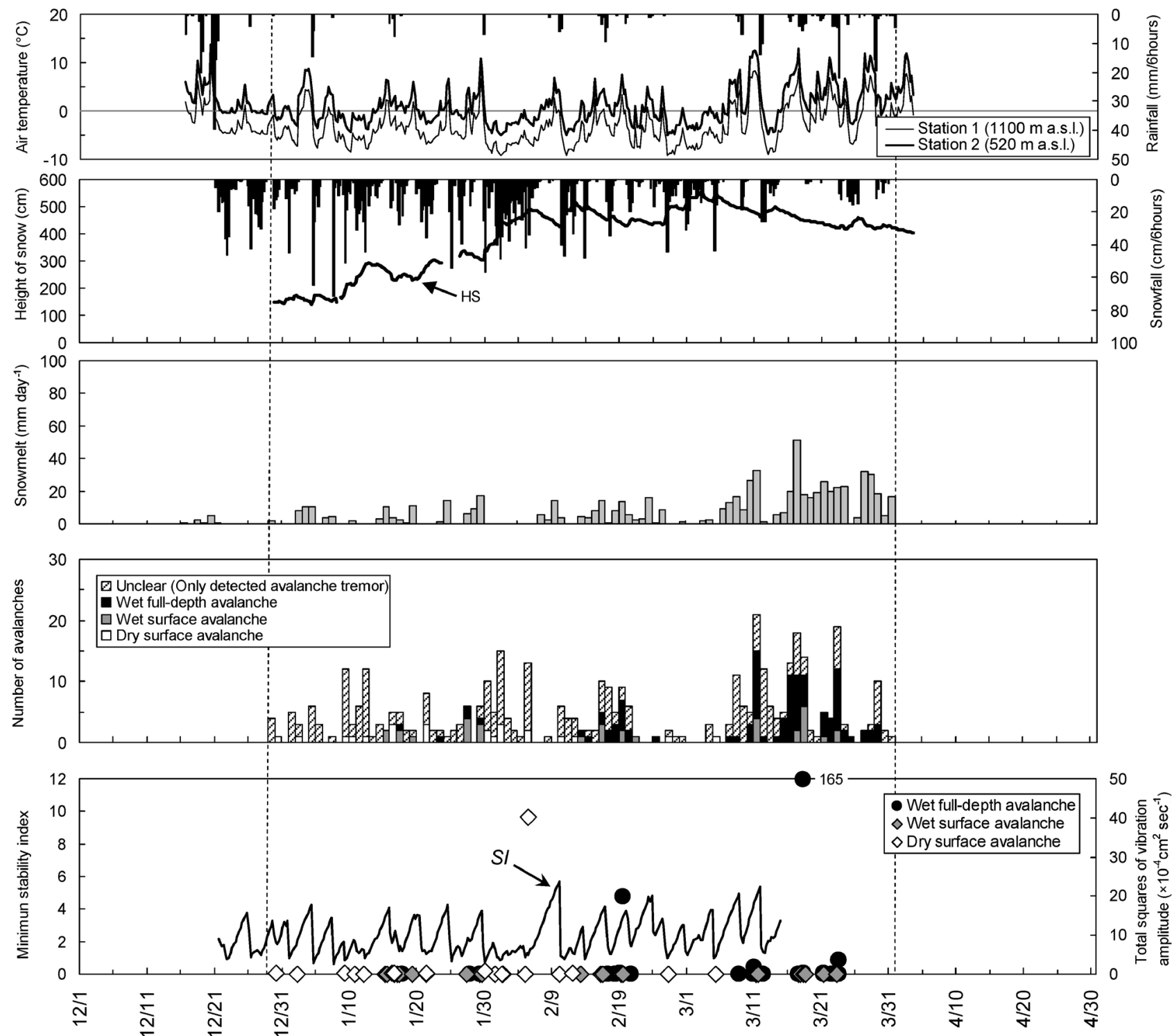

Fig. 17. Meteorological conditions, daily snowmelt, avalanche events, and variation in the snow stability index (Dec. 2004Mar. 2005).

(a) Air temperature at station 1 (calculated using temperature lapse rate: $0.72^{\circ} \mathrm{C} / 100 \mathrm{~m}$ from station 2 ) and at station 2 , and rainfall at station 3 .

(b) Snow depth and snowfall at station 2.

(c) Daily snowmelt (calculated for station 2).

(d) Number of avalanches per day, based on avalanche tremor and video records. 'Unclear' refers to events recorded only in the seismic data.

(e) Snow stability index (calculated) and the total squares of seismic amplitude of avalanche tremors (vertical motion) on slopes S1, S2, and S3.

5.5 Weather conditions and avalanche events in winter 2004-2005

Figure 17 shows the meteorological conditions, daily snowmelt, avalanche events, and variation in the snow stability index (SI) for the winter of 20042005. Air temperature at stations 1 and 2 exceeded $0^{\circ} \mathrm{C}$ from January 3 to 4 , January 15 to 16 , January 27 to 29, February 19 to 20, March 7 to 8, and March 10 to 11 , and often exceeded $0{ }^{\circ} \mathrm{C}$ continuously after March 16. Continuous snowfalls were recorded from January 5 to 14 , January 17 to 19 , January 30 to February 5 , February 10 to 14 , and February 26 to March 5, but it snowed little after March 13. Daily snowmelt could be calculated almost continuously from February 7 to 25 and after March 6. The highest amount of daily snowmelt was approximately $51 \mathrm{~mm}$ on March 17, and snow cover often melted at a rate of more than $20 \mathrm{~mm}$ per day after March 10.

The video data recorded 24 dry surface avalanches, no dry full-depth avalanches, 34 wet surface avalanches, and 97 wet full-depth avalanches. Dry surface avalanches were recorded when SI values ranged from 0.8 to 2.3. Two dry surface avalanches released on January 16 occurred after snowfall at an 
SI value of 2.3, and the other dry surface avalanches occurred during snowfall when $S I$ values ranged from 0.8 to 1.9 . No dry surface avalanches were present in the video record after March 6.

Wet surface avalanches occurred five times from January 15 to 16 , seven times from January 27 to 29, five times from February 16 to 19, four times on March 11, eight times from March 17 to 18, and three times from March 21 to 23; no wet surface avalanches were recorded after March 24. Wet full-depth avalanches occurred three times from January 27 to 29, 14 times from February 16 to 20, 15 times from March 10 to 12 , 39 times from March 14 to 18, and 20 times from March 21 to 24; after March 24, only wet full-depth avalanches occurred.

The dry surface avalanche on slope S1 on February 5 was large $\left(I>5 \times 10^{-4} \mathrm{~cm}^{2} \mathrm{sec}^{-1}\right)$ and occurred during snowfall when the $S I$ value was 1.3. The duration time of its avalanche tremor waveform was 56 seconds. The wet full-depth avalanche on slope S1 on February 19 was also large and had a tremor waveform duration of 74 seconds. The wet full-depth avalanche on March 18 was the largest of winter 20032004, and its avalanche tremor waveform lasted 143 seconds.

\section{Conclusions}

Many avalanches occurred during the 459 days of field observations over four winters (December 2001 to March 2005). The major results are highlighted below.

1) The avalanche observations included 3386 vibration events, of which avalanches caused 1504 (about 44\%). Video records were obtained for 727 avalanches.

2) Of the 727 video images of avalanches, 83 were dry surface avalanches, four were dry full-depth avalanches, 157 were wet surface avalanches, and 483 were wet full-depth avalanches. Wet avalanches accounted for about $88 \%$ of all the avalanches.

3) Approximately $97 \%$ of the avalanches (707 avalanches) occurred on slopes S1, S2, and S3, and of these, approximately 59\% (431 avalanches) were on slope S1, which is where the avalanche disaster of January 26, 1986, initiated.

4) Dry surface avalanches occurred with $S I$ values ranging from 0.8 to 3.2 , and about $92 \%$ of dry surface avalanches occurred during snowfall with $S I$ values ranging from 0.8 to 2.4; these events are assumed to have been caused by the lower $S I$ values within the newly accumulated snow.

5) Wet avalanches occurred frequently during and after March each year when the air temperature continuously exceeded $0^{\circ} \mathrm{C}$, and even occurred during January and February when the air temperature was high. Wet full-depth avalanches increased in frequency as snowmelt increased; beginning in mid-
March, most avalanches were wet full-depth avalanches, and beginning in April, only wet full-depth avalanches took place.

Avalanche tremors cannot be attributed to a particular avalanche type unless video images are also available. Developing a method of determining avalanche type based on avalanche tremors is an important challenge for future work.

\section{Acknowledgment}

The authors thank the establishment of observation sites to Nou-town office and Mr.Saito, head of Maseguchi district, and thank using observation data for Earthquake Observation Center of Earthquake Research Institute in the University of Tokyo. They also thank to K. Ojima for data reduction of avalanche video image, and thank to S. Sato, T. Uchida and Y. Naito for maintenance of the avalanche observation site and field survey assistance.

\section{References}

Akitaya, E. (1973): Observations of Avalanches with a VideoTape Recorder (in Japanese), Low Temp. Sci., Ser, A, Phys. Sci., 31, 287-289.

Akiyama, K., Takeshi, T., Hanaoka, M. and Ikeda, S. (2007): Dynamic observations focused on dry avalanche and occurrence conditions of large scale dry slab surface avalanche, Bull. Glaciol. Res., 24, 109-121.

Bessason, B., Eiriksson, G., Thorarinsson, O., Thorarinson, A. and Einarsson, S. (2007): Automatic detection of avalanches and debris flows by seismic methods, J. Glaciol., 53, 182, 461-472.

Endo,Y. (1993): Forecasting of direct-action avalanches in terms of snow accumulation rates (In Japanese with English abstract), Seppyo, 55, 113-120.

Imanishi, N., Nishimura, K., Moriya, T. and Yamada, T. (2004): Observations of seismic signals induced by snow avalanches (in Japanese with English abstract), Seppyo, 66, $3-10$.

Izumi, K. and Kobayashi, S. (1986): The movement of a powder snow avalanche as recorded on a seismograph (in Japanese with English abstract), Annual Report of the Research Institute for Hazards in Snowy Areas, Niigata University , 8, 99-104.

Kobayashi, S. (1986): On the powder snow avalanche, which occurred in Maseguchi, Nou-machi. Niigata prefecture, 1986. (in Japanese), Seppyo, 48, 87-91.

Kojima, K. (1979): Mechanism of snowmelt and heat balance (in Japanese), Meteorological Research Note, Meteorological Society of Japan, 136, 1-38.

Kurobe Avalanche Measurement Group (Ed.) (1989): KUROBE HOU AVALANCHE - Studies of Powder-snow Avalanches in Kurobe Canyon - (in Japanese), Contributions to Mountain Sciences, No. 2, Tateyama Laboratory of Mountain Sciences, Toyama University, $91 \mathrm{pp}$.

Muramatsu, I. (1993): Jishinkei ni yoru nadare kansoku (in Japanese), Kisyo, 37, 4-8.

Narita, H. and Shimizu, H. (1975): Distribution of Snow Avalanches in the Avalanche Station Area, Toikanbetsu, Northern Hokkaido. I. (1974) (in Japanese), Low Temp. Sci., Ser, A, Phys. Sci., Data report, 32, 40-54.

Narita, H. and Shimizu, H.(1976): Distribution of Snow Avalanches in the Avalanche Station Area, Toikanbetsu, Northern Hokkaido. II. (1975) (in Japanese), Low Temp. 
Sci., Ser, A, Phys. Sci., Data report, 33, 35-46.

Narita, H. and Shimizu, H. (1977): Distribution of Snow Avalanches in the Avalanche Station Area, Toikanbetsu, Northern Hokkaido. III. (1975-1976) (in Japanese), Low Temp. Sci., Ser, A, Phys. Sci., Data report, 34, 27-38.

Narita, H. and Shimizu, H. (1978): Distribution of Snow Avalanches in the Avalanche Station Area, Toikanbetsu, Northern Hokkaido. IV. (1977) (in Japanese), Low Temp. Sci., Ser, A, Phys. Sci., Data report, 35, 35-44.

Nishimura, K. and Izumi, K. (1977): Seismic Signals Induced by Snow Avalanche Flow, Natural Hazards, 15, 89-100.

Ohno, H., Yokoyama, K., Kominami, Y., Inoue, S., Takami, S. and Wiesinger, T. (1998): Catch ratios of gauges for solid precipitation in Hokuriku region (in Japanese with English abstract), Seppyo, 60, 225-231.

Roch, A. (1966): Les declenchements d' avalanches, Int. Ass. Sci. Hydrol. Publ., 69, 182-192.

Sabot, F., Naaim, M., Granada, F., Surinach, E., Planet, P. and Furdada, G. (1998): Study of avalanche dynamics by seismic methods, image-processing the techniques and numerical models, Ann. Glaciol., 26, 319-323.

Shimizu, H., Akitaya, E., Nakagawa, M. and Okabe, T. (1972): Study on the Avalanche of Shiai-Dani Valley, Kurobe Canyon I : Preliminary Observation. (in Japanese with English summary), Low Temp. Sci., Ser, A, Phys. Sci., 30, 103-114.

Shimizu, H., Akitaya, E., Huzioka, T., Nakagawa, M. and Kawada, K. (1973): Study on High-Speed Avalanches of
Kurobe Canyon II. (in Japanese with English summary), Low Temp. Sci., Ser, A, Phys. Sci., 31, 179-189.

Shimizu, H., Huzioka, T., Nakagawa, M., Kawada, K., Akitaya, E. and Narita, H. (1974): Study on High-Speed Avalanche in Kurobe Canyon III. (in Japanese with English summary), Low Temp. Sci., Ser, A, Phys. Sci., 32, 113-127.

Shimizu, H., Huzioka, T., Akitaya, E., Narita, H., Nakagawa, M. and Kawada, K. (1975): Study on High-Speed Avalanche in Kurobe Canyon IV. (in Japanese with English summary), Low Temp. Sci., Ser, A, Phys. Sci., 33, 109-116.

Shimizu, H., Huzioka, T., Akitaya, E., Narita, H., Nakagawa, M. and Kawada, K. (1978): Study on High-Speed Avalanche in Kurobe Canyon V: Winters of 1975-1976 and 1976-1977. (in Japanese with English summary), Low Temp. Sci., Ser, A, Phys. Sci., 35, 117-132.

Suizu, S. (2002): A hazard evaluation model of dry snow avalanches caused by heavy snowfall (in Japanese with English abstract), Seppyo, 64, 1, 15-24.

Takeuchi,Y., Hirashima, H., Izumi, K., Kamiishi, I., Kawashima, K., Yamaguchi, S., Miyazaki, N., Nishimura, K., Evgeniy, P., Suzuki, T., Murakami, S. and Endo,Y. (2009): The largescale dry slab avalanche of February 2008 at Makunosawa valley in Myoko, Japan (in Japanese with English abstract), Seppyo, 71, 167-176.

Tsukuda, T. and Mizoue, M. (1988): Avalanche Tremors Detected by Seismometers (in Japanese with English abstract), Zisin, J. Seismol. Soc. Jpn., 41, 47-57. 